\title{
Transformation of the Cosmetic Industry Due to the COVID-19 Pandemic
}

\author{
Mega Farisha ${ }^{1}$, Hartoyo ${ }^{2}$, Arief Safari ${ }^{3}$ \\ 1,2,3Business School, IPB University, Bogor 16128, Indonesia.
}

Corresponding Author: Mega Farisha

\begin{abstract}
The Covid-19 pandemic that occurred caused external shocks to every company, without exception, companies engaged in the cosmetic sector. This study aims to analyze the company's external factors that affect the strength of the company's external side and assess whether there is a potential for market development. This study uses a qualitative approach using PESTEL analysis. Data were obtained from interviews with resource persons related to cosmetic products (facial serum) and also from literature in the Jabodetabek area. This study resulted in a key success factor that can be adopted by businessman, namely understanding the behavior of cosmetic consumers, especially facial serum. By understanding consumer behavior, businessman can determine appropriate strategies according to each consumer group and can also improve the trademark performance of each facial serum business actor. In addition, the importance of innovating, transforming, and adapting quickly to a phenomenon (in this case the Covid-19 pandemic) makes business not stagnant, continues to grow and is able to capture new market potential.
\end{abstract}

Keywords: cosmetic, Covid-19, facial serum, key success factor, PESTEL analysis

\section{INTRODUCTION}

The cosmetic industry is a very promising industry today considering the increasing public concern for appearance.
The cosmetic industry in Indonesia, especially the Jabodetabek area has great potential to develop, especially now that not only women are aware of cosmetics, men are now paying more attention to appearance (Ministry of Industry 2019). The emergence of local products is also considered capable of attracting the domestic market considering that these products are easy to obtain, competitively priced and suitable for the skin of the Indonesian people. However, the outbreak of the COVID-19 pandemic which has been declared a global pandemic has shaken almost all sectors, including the cosmetic industry. This pandemic requires people to minimize mobility and are advised to do everything from home.

However, businessman engaged in cosmetics do not stay silent, they always do positive things so that the demand for cosmetics increases. One of the most drastic developments during this pandemic is skincare products especially facial serum. With a lot of time at home, it makes people more flexible to do facial treatments at home. In addition, there is an obligation to use a mask, if not treated it will cause allergic or irritating effects. So that the proliferation of skincare products that appear as a result of the increasing demand for these products.

This research will focus on analyzing how changes in the cosmetic industry during the pandemic took place, using situational analysis (PESTEL Analysis). The objectives of conducting this 
analysis are finding external factors that can currently affect the company, identify external factors that may change in the future, and take advantage of opportunities or can avoid external threats. The benefits of conducting a PESTEL analysis are a very useful tool for understanding the overall picture of the environment in which the business operates, including an overview of the opportunities and threats that surround it. So, in taking the opportunity to minimize the risk. PESTEL analysis can also be a tool that can be used to understand all risks associated with business developments and declines, business position, and the direction of future business strategies. Besides that, this analysis can be a tool that can be used to analyze whether other businesses and events or phenomena that occur outside the business can affect the business or company (Valdemarin 2015).

\section{RESEARCH METHODS}

This research is qualitative by using PESTEL analysis, which is a form of analytical technique to identify external forces that can affect the company, which is also known as situational analysis. PESTEL analysis is a development of the PEST analysis which was first carried out by Francis Aguilar (1967). PEST stands for political, economic, sociocultural, and technological (figure 1). For PESTEL there are additional factors, namely environmental and legal/law. In this study, the use of situational analysis is closely related to the discussion regarding the ongoing Covid-19 pandemic issue. So that using this analysis is able to represent the impact that affects a company from this pandemic, can see the strength of the external side of the company, and the opportunity for new market potential. With this condition, it can determine the key success factors that affect the company at a macro level to be able to remain competitive and develop. Sampling was done by conducting direct interviews with parties related to the cosmetic industry and supported by literature studies. PESTEL analysis is an effective analytical technique to identify external forces that affect the company. This side of strength needs to be analyzed considering that it can create both an opportunity and a threat (Ward and Peppard 2002). Key success factors are competitive factors that can influence the industry to develop. In marketing, before any type of strategy or company plan can be implemented, it is important to do a situational analysis, and one way to do a situational analysis is to use PESTEL analysis.

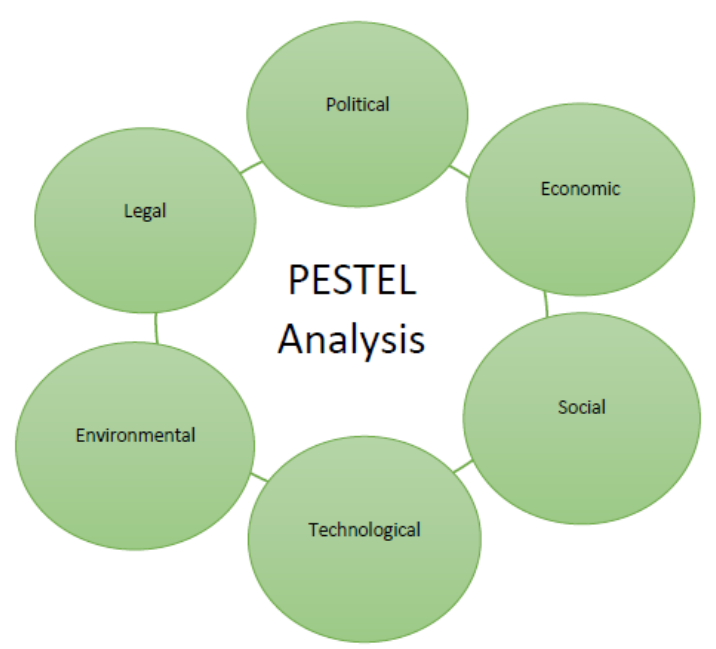

Figure 1. PESTEL Analysis (Wheelen \& Hunger 2012)

\section{PESTEL analysis factors include:}

\section{a) Political factors}

On political factors, it will look at the position of government intervention in economic activities. This consists of government policies, political stability, foreign trade policies, policies related to taxes, labor laws, trade restrictions, and so on.

\section{b) Economic factors}

Economic factors have an impact on how a company does a business and is profitable. These factors include economic growth, interest rates, exchange rates, inflation, consumer income, and so on.

\section{c) Sociocultural factors}

Sociocultural factors or what are often called social factors have a direct effect on how businessman can understand consumers and can find things that 
become the attraction of a product. These factors include population growth, age, health awareness, career and so on.

\section{d) Technological factors}

Technological factors are factors that are constantly change and this condition will have an impact on businessman in making sales. There are three ways that technology factors influence the marketing and management sectors involved:

1. New ways of producing a product

2. New ways of distributing products

3. New ways of establishing communication or interaction with the target market

e) Environmental factors

Environmental factors are associated with increased waste or pollution. In marketing a product, businessman in serving consumers to produce products can affect the environment. This factor can influence the purchasing decisions of the target market on the quality of a product and waste management after the product is produced.

\section{f) Legal factors}

To make a business successful, businessman must know the legal aspects that can support or hinder business processes. These factors include matters related to health and safety, equal product opportunities, standards of advertising, consumer rights and laws, product labeling and product safety.

\section{RESULT AND DISCUSSION}

Based on the results of interviews that have been conducted on several sources, the following is PESTEL's analysis of facial serum cosmetic companies during the pandemic Covid-19.

\section{Political Factor Analysis}

In the conditions of the Covid-19 pandemic, the government made several provisions related to restraining the spread of the virus, namely the implementation of
PSBB and continued by PPKM to several levels and adaptation of new habits (new normal), in the hope of limiting community mobilization so that it can narrow the space for the spread of the virus. The application of this system is applied according to the conditions of each region. The implementation of this system is actually effective in suppressing the rate of virus transmission, but also has resulted in several industrial sectors being affected by this, including the cosmetic industry sector. However, with the new normal conditions, there is a changing trend in the cosmetic industry, namely a trend in sales using online channels. It is undeniable, online sales systems such as using e-commerce or marketplaces make the cosmetic industry still able to distribute its products without having to do it through existing outlets.

In addition, the application of strict health protocols in this industry can convince potential consumers to use related products because they have adapted to new habits in society. Businessman must move actively to innovate in order to survive and be able to develop and be competitive.

\section{Economic Factor Analysis}

The Covid-19 pandemic triggered an economic crisis that hit Indonesia in 2020. Throughout 2020, Indonesia experienced an economic contraction in the 2nd and 3rd quarters, causing Indonesia to enter a recession. One of the causes of this economic downturn is the decline in purchasing power. This condition is exacerbated by restrictions on community mobilization so that it affects the demand for products, including cosmetic products (face serum). This situation demands that the cosmetic industry continues to innovate, transform, and adapt aggressively. One of the things that businessman actively doing is taking advantage of the pandemic situation by conducting various trainings related to capacity building including discussions related to health protocols, discussions about the latest cosmetic trends or trends, 
even conducting analysis related to digital sales using e-commerce and marketplaces.

Based on data obtained from BPOM (Food and Drug Supervisory Agency), throughout 2019 there were around 73,000 permits related to cosmetic notifications issued by BPOM and in 2020 this number increased to 75,500 permit notifications. This condition shows that the cosmetic business is growing even in the face of a pandemic (fimela.com, 2021). This happens considering that Indonesia has the potential to produce quality, environmentally friendly cosmetics and has the potential to be eyed by the world, considering that Indonesia is rich in various raw materials. The fulfillment of the domestic market and the opportunity to export create opportunities and challenges to continue to grow and develop the cosmetic industry. There are several things that cause the high potential for cosmetics to continue to develop in Indonesia, namely the high number of productive age population who have the potential to become potential consumers of products, the increasing economic growth in Indonesia, and the growing use of social media that can become a means of marketing products.

Along with the adaptation phase of new habits (new normal), the trend of recovery also occurs in cosmetic products. In large urban areas, the trend of recovery is towards skincare products, and in smaller urban areas the trend is towards makeup products. With this trend of recovery, it is an opportunity for business players to increase market share, and the initial key to seizing this opportunity is to understand the behavior of each consumer group so that they can determine the right strategy.

\section{Social Factor Analysis}

In the current condition, facial serum cosmetic products are mushrooming and crowded in the market, thus providing various alternatives for consumers to choose suitable ingredients and according to skin conditions. The trend of having a halal logo is also an added value for the product. This halal logo aims to be able to penetrate the target market that focuses on the halal content in the facial serum. However, behind the embedding of the halal logo, it is not immediately possible. The process which is quite time consuming and not free makes many business actors overwhelmed in getting the halal logo on their products, so that even though the product content and processing does not use haram ingredients, they cannot directly embed the halal logo, it takes a long time and must be approved by the competent authority.

In addition, in marketing products, the current trend of businessman choosing to use reference groups in the form of experts, influencers and determining brand ambassadors in the mission of increasing product sales. This is important because this reference group is capable of combing through various levels of society.

\section{Technological Factor Analysis}

Most of the sales related to cosmetics including facial serums are basically done offline or directly at outlets. The Covid-19 pandemic has accelerated changes in trade flows and patterns from offline to online, especially in the Greater Jakarta area. This is supported by the facilitation of internet access and communication in this area, so that it is easier for potential consumers to obtain the desired product. In addition, the existence of access or applications developed by businessman in trying virtually the products offered, makes online sales increasingly preferred by the public. This condition is carried out by businessman to stay close to consumers even though they are only digitally close. Among other things, beauty tech (Perfectcorp.com, 2021) uses AR (Augmented Reality) and AI (Artificial Intelligence) technology to boost sales. AR technology allows potential consumers to conduct virtual trials so as to make consumers feel a different digital experience and make consumers make the right purchase decisions on decorative cosmetics. It doesn't just stop at AR technological, with 
the combination of AR and AI technology it is possible to virtually test skincare products. This AI technology is able to provide an overview for potential consumers with various skin types to be able to choose products that suit their skin conditions. This technology can also be used for facial serum products, namely by doing the initial settings on the application (setting the skin type of prospective customers) which will then be directed to the appropriate product. The use of AR and AI technology creates new market opportunities for cosmetic business players including local facial serums to achieve targets and increase sales even though the pandemic situation continues for a long time.

\section{Environmental Factor Analysis}

The issue of the Covid-19 pandemic which has made almost all activities limited and carried out from home, including work. This situation is actually a good opportunity to be able to regulate a healthy lifestyle, including in terms of regulating facial skin health. This is thought to have made the public more aware of the importance of taking care of the face and the opportunity to take care of the face which can be done optimally because of the implementation of WFH and resulted in an increase in skincare sales in the midst of a pandemic. In addition, with the mandatory use of masks when traveling, making the area covered with masks if not treated will cause side effects in the form of irritation or allergic effects. This is in line with the facts revealed from the results of research conducted by Inventure-Alvara in June 2021, namely as many as $78.2 \%$ of respondents from a total of 532 people spread across 7 major cities in Indonesia who buy skincare products more often than decorative makeup products due to WFH (Swaonline 2021). According to this study, there is a shift in the use of beauty products, from makeup to skincare. Actually, since 2019 in the United States and England, it has been shown that the tendency of beauty product buyers to buy skincare products. With this global pandemic phenomenon, there has been a significant shift towards skincare.

\section{Legal Factor Analysis}

Business actors engaged in the cosmetic sector are obliged to ensure that the products produced are standardized by having certification that passes the BPOM test and is free from substances that can harm the skin. This is a form of responsibility that must be carried out by the industry as a form of protection for consumers. With this pandemic, considering the increasing demand for cosmetics, one of which is facial serum, it creates a potential market that is potential to be cultivated, and it is undeniable that many irresponsible parties take the opportunity. One of them is the increasing circulation of facial serum under the guise of a doctor's prescription, which in fact, if something is a doctor's prescription, will not be sold freely (voice.com 2020). In addition, there are also many fake cosmetics and skincare circulating that are vulnerable to online sales.

Actually, counterfeit products can be avoided by consumers in several ways, for example, consumers always check the history of online stores as a place to sell products. Consumers are also required to be more proactive in knowing the product to be purchased and pay attention to the product and its description. No less important, consumers are also required to read reviews from other consumers who have purchased products online at that place. To ensure that certain brands are clear of authenticity, consumers can also check them on the official website, social media or contact center at BPOM. In addition, businessman can also create second brand products while still carrying the initial brand so that similar products can be used by the public at a cheaper price.

Based on the PESTEL analysis above, it can indicate a tendency for changes to occur as well as early indications 
of consumer needs for a product or service (Palupiningrum, 2015; Gunawan, 2019). The key success factor that can be adopted by businessman is understanding the behavior of cosmetic consumers, especially facial serum. By understanding consumer behavior, businessman can determine appropriate strategies according to each consumer group and can also improve the trademark performance of each facial serum business actor (Gregoric 2014). In addition, the importance of innovating, transforming, and adapting quickly to a phenomenon (in this case the Covid-19 pandemic) makes business not stagnant, continues to grow and is able to capture new market potential.

This pandemic phenomenon has caused businessman to experience external disturbances which, if not addressed, can have an impact on the company's internals and even the loss of consumers. The importance of businessman in innovating, transforming, and making quick movements in adapting to this pandemic situation makes businessman able to capture market opportunities. The technology that is developing rapidly at this time has turned out to be able to make businessman succeed in maintaining their existence, as evidenced by the fact that even facial serum sales are basically done directly at outlets, but also can take advantage of the AR and AI technology that is currently developing, so there is no doubt for consumers. to buy facial serum products online. The ability of businessman to adjust to using this technology can also facilitate the needs of consumers so that there is closeness even though they are virtual.

However, with the high number of transactions made online, there is the potential for the proliferation of counterfeiting of cosmetic products, which are usually marked by slanted or nonstandard prices. Counterfeiting cosmetic products will cause harm to consumers. Not only that, but also counterfeit products will endanger consumers, considering that nongenuine products do not go through a hygienic process in the laboratory, so they are prone to causing health problems for consumers. Businessman should be able to catch this condition by finding solutions that can overcome this problem and so that consumers get original products. One way for businessman to overcome this is the need to educate potential consumers so that they are careful in buying products. In addition, businessman also need to think about making a second brand with quality that is not much different, original, but at a cheaper price.

\section{CONCLUSION}

This pandemic phenomenon has caused businessman to experience external disturbances which, if not addressed, can have an impact on the company's internals and even the loss of consumers. The importance of businessman in innovating, transforming, and making quick movements in adapting to this pandemic situation has made businessman able to seize market opportunities. The technology that is developing rapidly at this time has turned out to be able to make businessman succeed in maintaining their existence, as evidenced by the fact that even facial serum sales are basically done directly at outlets, currently they can take advantage of the AR and AI technology that is currently developing, so there is no doubt for consumers. to buy facial serum products online. The ability of businessman to adjust to using this technology can also facilitate the needs of consumers so that there is closeness even though they are virtual. However, with the high number of transactions carried out online, there is the potential for the proliferation of counterfeiting of cosmetic products, which are usually marked by slanted or non-standard prices. Counterfeiting cosmetic products will cause harm to consumers. Not only that, but also counterfeit products will endanger consumers, considering that non-genuine products do not go through a hygienic process in the laboratory, so they are prone to causing health problems for consumers. Businessman should be able to catch this 
condition by finding solutions that can overcome this problem and so that consumers get original products. One way for businessman to overcome this is the need to educate potential consumers so that they are careful in buying products. In addition, businessman also need to think about making a second brand with quality that is not much different, original, but at a cheaper price.

\section{Acknowledgement: None}

\section{Conflict of Interest: None}

\section{Source of Funding: None}

\section{REFERENCES}

1. Aguilar, Francis Joshep. (1967). Scanning the Business Environment. New York, Mc Millan.

2. Fimela.com. (2021). Melihat Perkembangan Industri Kosmetik di Indonesia Pasca Covid-19 [Internet]. Downloaded on September 1, 2021: https://www.fimela.com/beauty/read/45786 15/melihat-perkembangan-industrikosmetik-di-indonesia-pasca-covid-19.

3. Gregoric, Marina. (2014). PESTEL Anaysis of Tourism Destinations in the Perspective of Business Tourism (MICE). Conference: 22nd International Congress, Tourism \& Hospitality Industry 2014, Trends in Tourism and Hospitality ManagementAt: Hrvatska, Opatija, 08-09. 05. 2014.

4. Gunawan AI. 2019. Formulasi strategi distributor alat dan mesin pertanian (studi kasus pt bina pertiwi) [Master Tesis]. Bogor (ID): Institut Pertanian Bogor.

5. Kementerian Perindustrian [Kemenperin]. (2019). Kian Kinclong, Industri Kosmetik Nasional Tumbuh 20 Persen [Internet]. Downloaded on February 2, 2021: https://kemenperin.go.id/artikel/18954/Kian
-Kinclong,-Industri-Kosmetik-NasionalTumbuh-20-Persen.

6. Palupiningrum AW. (2015). Arsitektur Strategik Sekolah Bisnis Institut Pertanian Bogor [Master Tesis]. Bogor (ID): Institut Pertanian Bogor.

7. Perfectcorp.com. (2021). Beauty Tech: The Complete Guide 2021 [Internet]. Downloaded on August 21, 2021: Beauty Tech: The Complete Guide 2021 | PERFECT (perfectcorp.com).

8. Suara.com. (2020). Jangan Tergiur Kosmetik Murah, Krim Racikan Dokter Tidak Dijual Bebas [Internet]. Downloaded on August 20, 2021: Jangan Tergiur Kosmetik Murah, Krim Racikan Dokter Tidak Dijual Bebas! - Bagian 2 (suara.com).

9. SWAonline. (2021). Produk Kecantikan Lokal Semakin Diminati Konsumen [Internet]. Downloaded on August 21, 2021: https://swa.co.id/swa/trends/produkkecantikan-lokal-semakin-diminatikonsumen.

10. Valdemarin, Stefano. (2015). Analysis Regarding the Growing Presence of Italian Firms in Romania. Central European Business Review 4(4). DOI:10.18267/j.cebr.138.

11. Ward, John, Joe Peppard. (2002). Strategic Planning for Information Systems, 3rd Ed. Publisher: John Willey and Sons. ISBN:0470-84147-8.

12. Wheelen, Thomas L., David Hunger J. (2012). Strategic Management and Business Policy. McGraw-Hill Education Irwin. https://doi.org/10.1017/CBO978110741532 4.004 .

How to cite this article: Mega Farisha, Hartoyo, Arief Safari. Transformation of the cosmetic industry due to the COVID-19 pandemic. International Journal of Research and Review. 2021; 8(12): 627-633. DOI: https://doi.org/10. 52403/ijrr.20211276 